\title{
A política como espetáculo: a reinvenção da história brasileira e a consolidação dos discursos e das imagens integralistas na revista Anauê!
}

Rogério Souza Silva ${ }^{1}$

Universidade Estadual de Santa Cruz - UESC

Resumo

A revista Anauê! (1935-1937), uma publicação mensal degrandecirculação nacional, teve como meta a divulgação dos princípios da Ação Integral ista Brasileira(AIB) demaneiradidática. No seu primeiro número isso surge de forma bastanteclara: "Com o objetivo de divulgar, em linguagem acessível a todos, a doutrina integralista". A educação do olhar dos leitores desse periódico era al go essencial, por isso várias imagens fotográficas e desenhos estavam presentes em cada uma de suas edições. Em suas páginas, todos esses fatores confluíam na imagem redentora de Plínio Salgado, apresentado como a solução para os problemas que o Brasil vivia na década de 1930. Seus discursos e imagens buscavam uma divinização do movimento e do seu líder, além de uma reinvenção do passado histórico brasileiro.

Palavras-chave: Discursos; Imagens; Reinvenção; Política.

\section{ABSTRACT}

The Anauê! magazine (1935-1937), a monthly publication of great national circulation, had as goal the spreading of the principles of Ação Integralista Brasileira (AIB) in a didactic way. In its first number this appears under sufficiently clear form: "With the objective to divulge, in accessible language to all, the Integralista doctrine." The education of thereaders of this publication wassomething essential, therefore a great amount of photographic images and drawings was present in each one of its editions. In its pages all these factors joined in the liberator image of Plínio Salgado, presented as the solution for the problems that Brazil lived in the decade of 1930. Its speeches and images searched a divinization of the movement and its leader, beyond a reinvention of the Brazilian historical past.

Keywords: Speeches; Images; Reinvention; Politics. 
Essa idéia levou-o a estudar os costumes tupinambás ... Desde dez dias que se entregara a essa árdua tar efa, quando (era domingo) Ihe bateram à porta, em meio de seu trabalho. Abriu, mas não apertou a mão. Desandou a chorar, a berrar, a arrancar os cabelos, como se tivesse perdido a mulher ou um filho. A irmã correu lá de dentro, o Anastácio também, e o compadre ea filha, pois eram eles, ficaram estupefatos no limiar da porta.

- Mas que é isso, compadre?

- Queé isso, Policarpo?

- Mas, meu padrinho...

Ele ainda chorou um pouco. Enxugou as lágrimas e, depois, explicou com a maior naturalidade:

- Eis aí! Vocês não têm a mínima noção das coisas da nossa terra. Queriam que eu apertasse a mão ... Isto não énosso! Nosso cumprimento é chorar quando encontramos os amigos, era assim que faziam os tupinambás.

Lima Barreto ${ }^{2}$

\section{PODER, DISCURSOS E IMAGENS}

As sociedades são envoltas por um conjunto de símbolos historicamente construídos pelos homens e introduzidos nas mentes das sucessivas gerações. Para Hannah Arendt, "O s homens são seres condicionados: tudo aquilo com o qual eles entram em contato torna-se imediatamente uma condição de sua existência. 0 mundo no qual transcorre a vita ativa consiste em coisas produzidas pelas atividades humanas ...."3 $\mathrm{A}$ natureza e os artefatos são parte de um amplo universo de significações que permeiam todos os setores vida. Clifford Geertz afirma que "o homem éum animal amarrado a teias de significados que ele mesmo teceu, assumo a cultura como sendo essas teias ea sua análise". ${ }^{4}$ D entro de um determinado contexto cultural podemos pensar como as várias estruturas de poder (especialmente o poder político) se consolidam e como os distintos signos de uma determinada sociedade vão influenciá-las. Os signos são fatores que estão enraizados nas práticas cotidianas. Todas as formas de poder fazem uso deles na busca de uma legitimação diante das diferentes sociedades que querem dominar, seja para manter o status quo seja para alcançar mudanças. Essa ação também pode ser vista como uma teatra- 
lização, pois o poder precisa de um caráter cênico para que ele possa se consolidar, como mostra Georges Balandier (1982, p.5):

Por trás de todas as formas de arranjo da sociedade e de organização dos poderes encontra-se, sempre presente, governando dos bastidores, a "teatrocracia". Ela regula a vida cotidiana dos homens em coletividade. É o regime permanente que se impõe aos diversos regimes políticos, revogáveis, sucessivos. ${ }^{5}$

Vê-se que o poder precisa de instrumentos de representação teatral, não pode viver separado deles. 0 mesmo autor completa (p.7):

0 poder estabelecido unicamente sobre a força ou sobre a violência não controlada teria uma existência constantemente ameaçada; o poder exposto debaixo da iluminação exclusiva da razão teria pouca credibilidade. Ele não consegue manter-se nem pelo domínio brutal e nem pela justificação racional. Ele só se real iza e se conserva pela transposição, pela produção de imagens, pela manipulação de símbolos e sua organização em um quadro cerimonial. (p.7)

Portanto, o poder tem que se mostrar como se brotasse do chão do passado, para apontar os caminhos do futuro, como se estivesse predestinado a aparecer em um momento histórico ou a se perpetuar no comando de uma sociedade. Cultura e poder são fatores que possuem uma grande ligação.

A Ação Integralista Brasileira (AIB), movimento político que agiu no Brasil de 1932 a 1937, procurou usar todos os recursos do imaginário histórico brasileiro somado ao clima nacional e internacional da década de 1930 para criar seu projeto de poder. Com uma retórica nacionalista o movimento tinha em Plínio Salgado o seu líder. U ma partesignificativa de suas simbologias eram um abrasileiramento das que Benito Mussolini e Adolf Hitler estavam utilizando. É claro que a AIB também possuía vários elementos extremamente originais. Talvez por esta razão, a historiografia sobre o tema seja bastante dividida, especialmente entre aqueles que acreditam que o movimento fosse fascista e aqueles que descartam tal hipótese. Entre tantas, as obras de H élgio Trindade e José Chasin encarnam bem essas duas perspectivas. ${ }^{6}$

Se ficarmos apenas no campo da política as diferenças são significativas, como comprovam muitos textos escritos por quadros do movimento na época. ${ }^{7}$ Contudo, se caminharmos para o campo da semiótica e dermos importância às indumentárias, às formas de saudação, aos rituais, aí sim, o movimento podeser considerado como um parente em primeiro grau do fascismo. O próprio Plínio em 1930 (entre os meses de abril e outubro) fez uma longa 
viagem, como preceptor do filho de um advogado e banqueiro paulista, pela Turquia, I tália, Alemanha e Portugal, ${ }^{8}$ entre outros países, notando as mudanças pelas quais passavam essas nações. Sem a menor dúvida, o contato com tais realidades foi impactante em sua mente e serviu de referencial para os passos que el e daria a seguir.

Para os defensores do integralismo brasileiro o futuro não pertencia à democracia-liberal e a experiência soviética era execrável, portanto, diferentes modalidades de tipo nacionalista (fascismo, nazismo e integral ismo) deveriam triunfar. Porém, a carga si mbólica existente em cada sociedade daria os aspectos exteriores e interiores desses regimes. Dever-se-ia pensar em um regime que respeitasse as características histórico-culturais do Brasil e que fosse essencialmente nacionalista. A procura pelas características nacionais, a necessidade de se redescobrir a cultura nativa era al go que já vinha ocorrendo dentro das distintas correntes do M ovimento M odernista. Nos anos 200 próprio líder da AIB estava em sintonia com essas idéias que frutificaram em seus artigos e manifestos.

I déias como essas, para que al cançassem êxito, deveriam fazer uso das estratégias de propaganda existentes na Europa e que vinham sendo utilizadas com sucesso por fascistas e nazistas. N esse caso, a difusão da doutrina por meio de jornais, revistas, rádio e cinema adquiria grande importância. Nesses meios percebe-se toda a carga simbólica existente em tais movimentos. Os escritos e as imagens nos dizem muito. De todos os órgãos de imprensa criados pela AIB vê-se a revista de circulação nacional denominada de Anauê!, publicada no Rio de Janeiro entre 1935 e 1937 (havia outros periódicos integralistas com o mesmo título, mas esses eram de circulação regional). Essa publicação, que tem seu nome extraído do tupi ${ }^{9}$ (termo que também era o grito de saudação dos seguidores de Plínio Salgado), constitui-se em uma porta de entrada imprescindível para quem quer entender o imaginário político criado pelos integralistas. Anauêl era uma parte importante de um conjunto amplo de publicações existentes nos estados, juntamente com outros veículos de informação nacionais como, por exemplo, o jornal A O fensiva. Havia diferentes títulos integralistas de norte a sul, além de livros publicados pelos principais nomes do movimento. A revista Anauê! buscava propagar a unidade do integralismo sem perder de vista a pluralidade regional e cultural do país. Vale lembrar que seu surgimento se deu em 1935, no contexto em que a AIB tornava-se um partido político com registro no Superior Tribunal Eleitoral deixando, portanto, de ser apenas uma associação político-cultural. ${ }^{10} \mathrm{~A}$ perspectiva que os integralistas passaram a ter dealcançar o poder por meio deeleições nos dá a dimensão dessa revista como um mecanismo de propaganda. 
Vamos perceber, em todas as suas edições, a necessidade de resgatar o Brasil como nação. Nos escritos de seus pensadores o futuro estaria comprometido se não fossem tomadas medidas que mudassem todos os aspectos da sociedade brasileira. 0 integralismo como al go integral, ou seja, que abarcaria toda a sociedade, e o sigma ( $\mathrm{S}$ ) como símbolo da soma de todos os fatores são evidentes nas páginas dessa revista. Nisso uma releitura do passado era essencial, especialmente se ela enfatizasse os grandes fatos e os heróis da história oficial brasileira e estes tivessem no integralismo e no Chefe Nacional a reencarnação de todos os seus valores. Era como se o movimento representasse a união de posturas plenamente nacionais.

A Anauê! classificava-se como uma revista ilustrada. Ela seguia o padrão de outras da mesma categoria que circulavam no Brasil desde a metade do século XIX, aumentando em quantidade até o início do XX quando ocorre, em boa parte delas, um crescimento significativo de imagens fotográficas em relação aos desenhos presentes em suas páginas. O periódico da AIB possuía muitas imagens, as propagandas de produtos de consumo estavam presentes, buscava-se dar cobertura para os fatos nacionais e internacionais, e havia uma espécie de coluna social (nascimentos, casamentos, falecimentos...), além de uma seção de moda (Figura 1) que aparece de maneira irregular nos pouco mais de vinte números da revista. Todos os fatos que ela citava direcionavamse ao integralismo. A Anauê! surgiu como uma revista do movimento para o

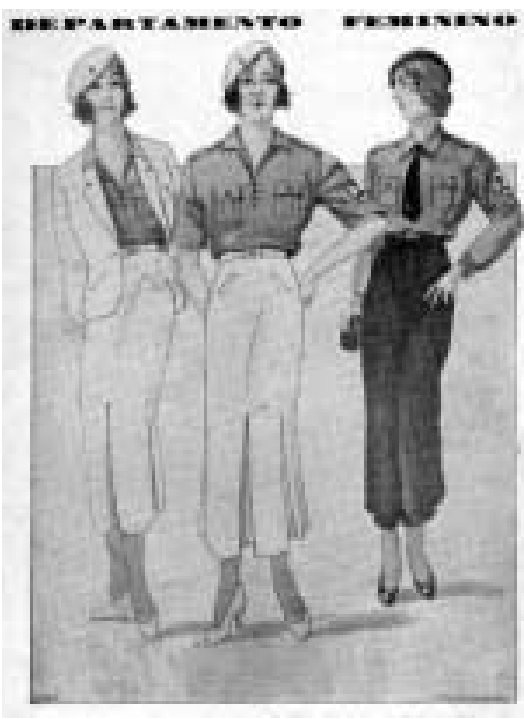

Figura 1 - A moda integralista: Havia uma grandequantidadedetemas nas revistasilustradas: política, assuntosliterários, seçõesinfantis efemininas. A Anauê!, apesar de seu caráter doutrinário, mantém esse perfil. $\mathrm{Na}$ imagem observam-se modelos de roupas destinadas às mulheres integralistas, as chamadas blusas-verdes. Anauê!, Rio de Janeiro, ago. 1935, ano I, n.3, p.51. 
movimento, não fazendo a menor questão de disfarçar essa finalidade (Figuras 2 e 3). Entretanto, ela absorveu um estilo de escrita jornalístico próprio de outras revistas ilustradas. O u seja, sua intenção era atingir o brasileiro letrado (ou razoavelmente letrado), com conhecimentos medianos e bastante sedento por imagens. Os principais nomes do movimento publicavam arti-
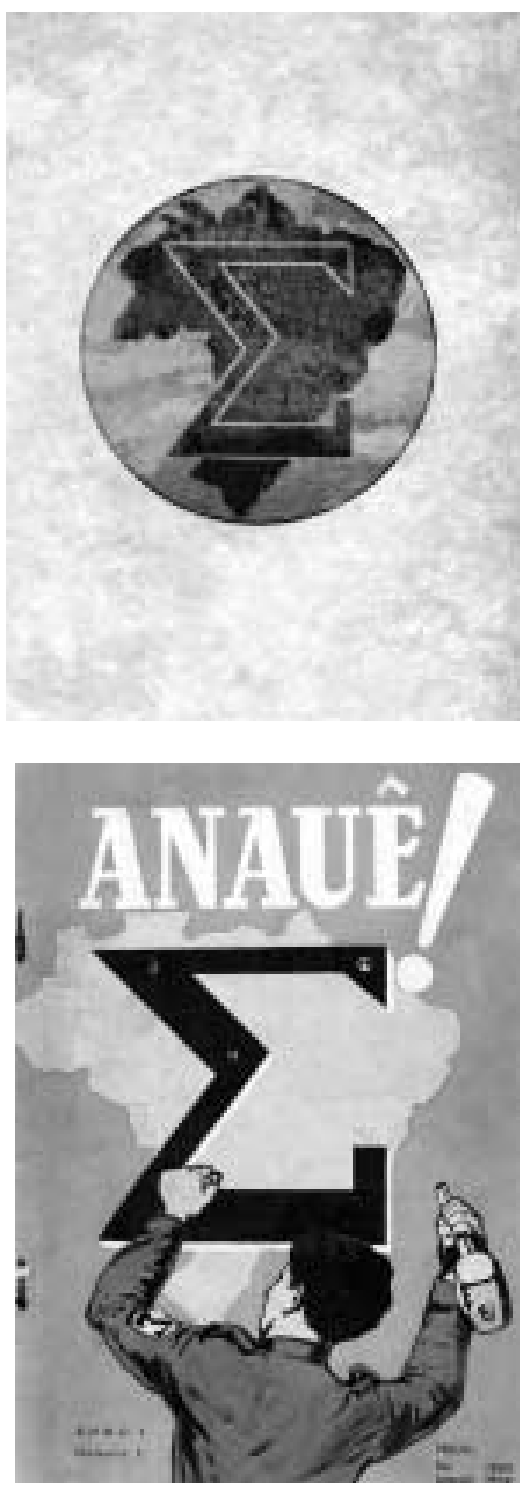

Figura 2 - 0 símbolo e o movimento: 0 sigma, 18a letra do alfabeto grego, era apresentado com estilos diferenciados em cada uma de suas edições. Anauê!, jan. 1935, ano I, n.1, p.7.

Figura 3 - A propaganda e o movimento: As capas de Anauê! são exemplos que expressam bem o peso que a propaganda passa a ter para todos os movimentos políticos. Anauê!, maio 1935 , ano I, n.2. 
gos na revista: Plínio Salgado, Gustavo Barroso, M iguel Reale eVictor Pujol, entre outros. As idéias mais sofisticadas que inspiravam os seguidores do sigma poderiam ser encontradas em obras específicas produzidas por esses mesmos escritores, ou em pensadores conservadores que serviam como referência, por exemplo, Alberto Torres, Jackson de Figueiredo ou Oliveira Vianna. É relevante notar que, apesar das diferenças, no conjunto das obras integralistas havia uma repetição de idéias entre os seus vários autores. No entanto, essas se davam com expressões distintas, havendo uma evidente separação entre as obras destinadas para uma elite intelectual, por conseguinte, mais elaboradas e racionais, eas obras destinadas ao povo, tendo estas últimas uma maior carga emocional. ${ }^{11}$ Os periódicos da AIB, na sua estruturação, equilibram-se entre a razão e a emoção. M uitas vezes a opção se deu mais pelo universo das emoções, como é o caso de Anauê!, pois, para seus elaboradores era muito claro que públicos diferentes mereciam linguagens diferentes. Essas questões são destacadas no editorial escrito em seu primeira número:

Com o objetivo de divulgar, em linguagem acessível a todos, a doutrina integralista; querendo refletir, na reportagem fotográfica de todas as Províncias, a marcha gloriosa das legi ões do Sigma; pretendendo ser o espelho da alma integralista, o periódico dos camisas-verdes de todas profissões, de todas as classes e de todas as idades, - surge a revista "Anauê!" amparada pela simpatia unânime de todos os companheiros, e jurando também fidelidade absoluta ao Chefe $\mathrm{Na-}$ cional, na adversidade ou na vitória, diante da vida ou diante da morte!

Aí está a "netinha" do Chefe: - pequenina, humilde, mas com vontade de crescer e de levar avante o importantíssimo programa que lhe foi traçado.

Cumpre agora aos "padrinhos", que são todos os camisas-verdes da Pátria, amparar a "afilhadinha", vesti-la com as melhores fotografias, alimentá-la com a vitamina duma colaboração substanciosa mas não indigesta e tudo fazer para que seja conhecida e amada em todos os lares brasileiros.

Integralistas! - Recebei a vossa revista. Ela é integralmente integralista, "dos integral istas e para os integralistas".

Aos irmãos do norte e do sul, do leste e do oeste, ANAUÊ! E a PLÍ N IO SALGAD O, Chefe Supremo e insubstituível, encarnação do Integralismo, nosso Irmão, nosso Amigo e nosso Guia, - apesar de todas as suas proibições - a nossa comovida homenagem, a nossa imorredoura gratidão, o nosso amor eterno!

Ao Chefe Nacional, três bárbaros e tonitruantes ANAUÊS!

(Anauê!, Rio de Janeiro, jan. 1935, ano I, n.1, p.3, grifos meus) 
Uma revista de política numa época em que essa palavra perdia grande parte de seu conteúdo filosófico e ganhava tons de espetáculo. A "netinha” do Chefe seria um símbolo de unidade da família integralista. Era como se aquela publicação passasse a ter vida própria.

A Anauêl consegue ser um significativo fragmento das tensões do mundo dos anos 30. O século XX foi, sem dúvida, o momento histórico no qual as simbologias em torno do poder ea necessidade de controlar e conquistar amplas camadas populacionais atingiram níveis globais. Se o século XIX é visto por muitos historiadores como o século burguês, o século XX, em contrapartida, foi, desde seus primeiros momentos, profetizado como o século das massas. Em Além do bem e do mal, publicado pela primeira vez em 1886, Friedrich Nietzsche notava uma mudança de padrões na Europa de fin de siècle com uma maior participação de pessoas em movimentos políticos. 0 filósofo via nos aglomerados humanos, que reivindicavam seus direitos e se organizavam politicamente, o anúncio de uma era em que predominaria o que el e chamava, pejorativamente, de animal de rebanho;, ${ }^{12}$ décadas depois J osé O rtega y Gasset, em A rebelião das massas (1926), falaria do homem- massa;, ${ }^{13}$ mais tarde, $\mathrm{H}$ annah Arendt, em Origens do totalitarismo (1950), teceria discussões muito profundas sobre a ralé que se identificou com o hitlerismo e com o stalinismo. ${ }^{14}$ $\mathrm{Na}$ visão desses diferentes intel ectuais as massas eram manipuláveis, os homens carismáticos tinham um poder quase hipnótico sobre elas, eisso significaria perigos em tons variados. Se mergulharmos no século XIX poderemos localizar as raízes dessas preocupações nas análises de Alexis de Tocqueville sobre a democracia americana e sua tirania da maioria, ${ }^{15}$ ou ainda no Dezoito do Brumário de Luiz Bonaparte, onde Karl M arx coloca uma distinção muito clara entre o proletariado, como agente da mudança e vanguarda revolucionária, e aqueles que formavam o lumpemproletariado, que deram apoio ao golpe de Estado do sobrinho-neto de Napoleão, em 1852, na França. ${ }^{16}$

A década de 1930 é considerada por muitos como uma materialização de todos esses processos. Um divisor de águas no qual as massas à direita eà esquerda tornavam-se peças relevantes. Sua entrada maciça como componente das lutas do período deve-se a uma série de questões econômicas, sociais e políticas. Contudo, as lideranças que se identificavam como suas representantes não conseguiram a sua adesão e fidelidade apenas por meio de um discurso político e racional. Há um termo central para se entender tais processos - imagem - , além de outros termos correlatos, como propaganda e manipulação. A construção da liderança, a construção do povo a ser liderado, a construção da nação e a reinvenção da história foram de grande re- 
levância para atrair parcelas significativas de homens e mulheres do mundo todo, para causas tão variadas, mas que utilizavam métodos bastante semeIhantes.

Pensar o movimento integralista traz à superfície dois aspectos presentes na cultura política brasileira: o messianismo ${ }^{17}$ e 0 autoritarismo. Juntamente com eles, a consolidação de processos históricos que levaram à estruturação de uma política de massa deu o tom dos discursos e imagens de Anauê!.

\section{EM BUSCA DE UMA ORIGEM DIVINA PARA O INTEGRALISMO E PARA O CHEFE NACIONAL}

Para se entender como se constituiu o que vejo como uma origem divina do integralismo e do Chefe $\mathrm{N}$ acional faz-se necessário ler uma pequena história citada em uma das edições de Anauê!, com o título de A gente acredita:

Uma [sic] cai pira estava lendo... a "Quarta Humanidade"!

Aproxima-se dele um bacharelzinho pedante e começa a zombar do pobre homem.

Então, quelivro é esse?

É a "Quarta Humanidade".

M as vocênão entende isso... É um livro muito difícil para você.

E o cai pira, que por várias vezes já tinha sido escarnecido pelo bacharel, perde desta vez a paciência e sai com esta:

Seu dotô; isso aqui é o livro do Chefe Nacioná. E o livro do Chefe Nacioná é cumo o Ivangel ho de Nosso Sinhô. Quando a gente não entende, a gente acredita, ouviu?

(Anauê!, jan. 1936, ano II, n.6, p.10.)

Esse relato é bastante exemplar para se entender as construções discursivas e as resultantes imagens que as lideranças integralistas tentavam projetar diante da sociedade na revista Anauê!. Há um claro objetivo em sacralizar o movimento, ${ }^{18}$ transformando-o em um conjunto de predestinações divinas. $N$ ão éà toa queno fragmento citado há a criação de um paralelo entre uma das principais obras de Plínio Sal gado, A quarta humanidade, e os Evangelhos.

Grande parte das ações políticas da AIB são permeadas por comparações bíblicas. Uma delas aparece na edição de março de 1936, quando ocorre um 
encontro de estudantes integralistas em São João Del Rei, M inas Gerais. Um dos presentes ao encontro faz o seguinte paralelo na Anauê!:

Descíamos de São João del-Rei como, há seis mil anos M oisés descera do Sinai. Trazíamos conosco os [sic] Taboas da Lei, as diretrizes traçadas pelo grande Chefe no alto da serra gigantesca, em mais intimo contato com o eterno.

(Anauê!, mar. 1936, ano II, n.8, p.11)

Em todos os exemplares da revista há um significativo número de textos que se referem às ligações existentes entre o integralismo e o cristianismo (a maior parte dos componentes do movimento era formada por católicos). ${ }^{19} \mathrm{Se}$ as doutrinas estão ligadas aos homens que foram seus precursores, também teriam pontos em comum. Eurípides Cardoso de M enezes, redator-chefe de Anauê!, compara Paulo de Tarso (o apóstolo Paulo), o difusor do cristianismo, a Plínio Salgado:

$\mathrm{Na}$ cristianização dos gentios o grande predestinado foi Paulo de Tarso. $\mathrm{Na}$ Salvação do Brasil, Plínio Salgado!

E a quem estuda a vida de ambos, não poderá escapar a extraordinária afinidade que os une por cima de vinte séculos!

Coloquemo-nos diante de Paulo de Tarso e de Plínio Salgado. Quanta semeIhança!

Paulo era senador, doutor da Lei, filósofo, escritor emérito e conceituadíssimo na sua cidade; tudo abandonou para se dedicar de corpo e al ma à Causa do Evangelho. Plínio Salgado, também filósofo e grande escritor, respeitado e querido na sua terra, tudo deixou, inclusive a cadeira de deputado, para se consagrar à Causa do Brasil, para ir de vila em vila, de cidade em cidade, pregar aos seus irmãos a doutrina redentora do Sigma!

A mbos sofrendo a separação da família, ambos franzinos fisicamente e duma resistência admirável; falando horas seguidas, pela noite a dentro, aos ouvintes insaciáveis e eletrizados.

(Anauê!, jan. 1936, ano II, n.6, p.4, grifos meus)

0 trecho mostra o integralismo e o cristianismo irmanados. Uma ponte de quase dois mil anos os une. Seus homens, também irmanados, são valorosos e suas causas semelhantes.

Uma outra construção, bem mais interessante e ousada que a anterior, ocorre nas tentativas de aproximação entre a figura de Plínio Sal gado e a de 
Jesus Cristo. Jorge Pinhei ro Brisola, Chefe do Departamento de Assistência Social da Secretaria Nacional de Organização Política, uma das seções da AIB, diz a esse respeito:

Amai-vos uns aos outros, - recomendou Jesus C risto, o doce nazareno de bondade e sabedoria infinitas, que pelo imenso amor que dedicou à humanidade, foi crucificado pelos homens ... Essa recomendação do Cristo não pode ser esquecida por nenhum homem capaz de elevar o espírito a um plano acima do materialismo dissolvente que envenena o mundo na hora que passa, e de compreender que o ser humano é al guma coisa diferente de uma simples peça de máquina. Plínio Salgado, o homem predestinado que desvendou aos brasileiros que sentiam o sofrimento da Pátria sem Ihe perceberem a causa profunda, o único rumo certo para atingir a salvação, quando lançou aos quatro cantos do Brasil a Doutrina Integralista, não esqueceu aquelas palavras do mestre.

(Anauê!, jan. 1935, ano I, n.1, p.42, grifos meus)

Os dois personagens estão unidos. As suas doutrinas, também unidas, são apresentadas como redentoras. A participação de membros da I greja Católica no movimento era bastante significativa. Entretanto, não devemos atribuir essas comparações entre homens contemporâneos e homens bíblicos à presença de religiosos dentro da AIB, pois, na verdade, elas iam contra muitos dogmas da I greja ao, praticamente, santificá-los em vida. No momento em que esses escritos veneram a figura de Plínio Salgado e do seu movimento, vê-se o predomínio da política na religião e não o contrário.

O redator-chefe de Anauêl faria outro paralelo, desta vez personificando o Brasil na figura bíblica de Lázaro, o morto que fora ressuscitado por Jesus Cristo. Este, obviamente, seria representado pelo Chefe Nacional.

E o supremo exemplo, o modelo perfeito é o próprio Chefe Nacional, o homem extraordinário que conseguiu operar o mais grandioso de todos os milagres: a ressurrei ção do Brasil, este Lázaro chorado por todos os que o amavam, e que jazia morto e já em adiantado estado de decomposição, não há quatro dias como o Lázaro do Evangelho, mas há quatro longos séculos! (p.14, grifos meus)

Fica evidente que a missão do líder da AIB era, em muitos aspectos, tão árdua quanto a de Jesus. Há uma clara percepção de que Plínio Salgado exerce um papel sobre-humano; suas características, destacadas em tais textos, 
são mais de um messias do que de um chefe de movimento político. 0 mesmo autor afirma:

Todavia, sendo o maior vulto do Brasil atual, éa própria simplicidade em pessoa. A modéstia do Chefe chega a ser desconcertante. Procura desaparecer, aniquilar-se, desviar de sua pessoa a menor homenagem, o mais discreto el ogio. " $\mathrm{A}$ Ofensiva" pretendia tirar uma edição especial a 22 de janeiro, data natalícia do Chefe. Ele proibiu. A revista "Anauê!" sairia nesse dia. Pediu-nos ele (e seu pedido é uma ordem), que lançássemos a revista mais tarde. Tencionávamos fazer uma proclamação a todos os camisas-verdes, do Amazonas ao Rio G. do Sul, do Atlântico às proximidades dos Andes, para que todos, às 16 horas do dia 22, numa poderosíssima comunhão de pensamento, se unissem impetrando ao Criador a Sua benção sobre Plínio Sal gado e sobre o movimento que ele dirige. 0 plano chegou ao conhecimento do Chefe e ele pediu que essa formidável concentração espiritual se fizessenão no dia 22 de janeiro, mas no momento da abertura do Congresso de Petrópolis, eem favor da Ação Integralista Brasileira! ( p.14)

Apesar da modéstia do Chefe e de sua aparente resistência a um culto de personalidade, todas as edições de Anauê! estão recheadas com frases laudatórias, como as já citadas. No primeiro número da revista havia um brinde no qual o leitor recebia uma foto de Plínio Salgado para que fosse emoldurada e (como estava recomendado) colocada na sala de visitas para que a família (e aqueles que visitassem tal casa) pudessem ver a imagem do líder. M antendo as devidas proporções, em outras experiências políticas do século XX, figuras como Stalin, Hitler e M ussolini tiveram uma divinização por parte dos órgãos de comunicação dominados pelos seus regimes. Vê-se, portanto, que a estratégia de divulgação de imagens e de construções discursivas de Anauê! está em sintonia com a sua época. Um momento histórico em que se consolida uma política de massas, mas isso não significando uma maior consciência e uma real participação daqueles que abraçavam determinadas idéias. Richard Sennett, ao discutir os processos históricos da Europa O cidental e dos Estados Unidos, vê no personalismo um sinal de crise política, uma decadência da cultura pública. ${ }^{20}$ A pesar das peculiaridades da realidade brasileira, que a tornam bastante distinta da existente no mundo do Atlântico Norte, algumas das análises do autor podem servir para decifrar a forma de agir dos integral istas. É inegável a ligação existente entre o excesso de personalismo e o momento de crise vivido pelo Brasil naqueles anos.

o Chefe Nacional eo movimento apareciam envoltos por uma aura mís- 
tica. Surgiam diante da sociedade brasileira no intuito de resgatá-la. Liderança e movimento, muitas vezes, apresentavam-se como um só corpo. O s camisas-verdes não atribuíam a ele nenhum poder divino, contudo, havia uma ênfase na sua bondade, no seu esforço, na sua inteligência, na sua humilde, na sua vontade de ir aos lugares mais remotos do país para divulgar a doutrina, na sua capacidade de conquistar adeptos. Tudo isso o diferenciava dos outros humanos; o caráter político da AIB (disputas, projetos, rivalidades) era substituído por um perfil religioso marcado pela sua predestinação. Seus intelectuais escreveram obras pregando uma Revolução do Espírito, contra o materialismo reinante no mundo. Um reflexo disso aparece em uma homenagem que Anauê! fez a três integralistas que haviam sido mortos em conflitos com seus opositores. N ela vamos ver uma noção bem peculiar de vida post-mortem (Figuras 4 e 5), pois quem perdia a vida pela causa era "transferido para

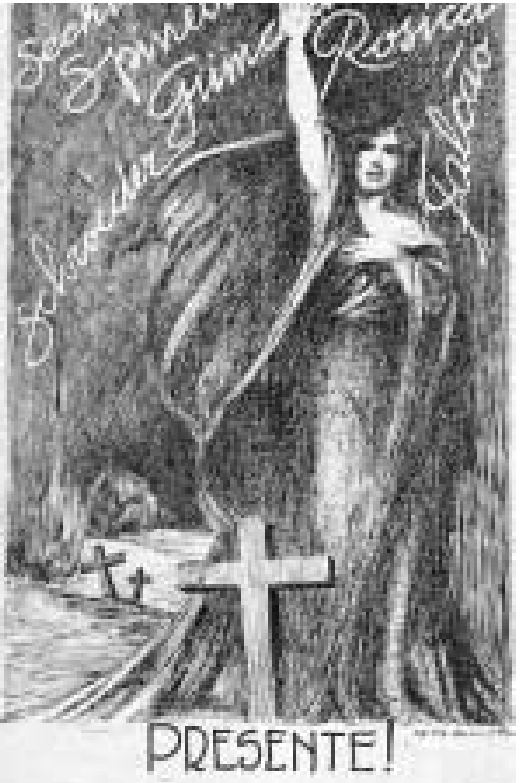

Figura 4 - Paraíso verde: Uma imagem religiosana qual umamulher, representando avida além-túmulo, faz a saudação romana. Ao fundo lêem-seosnomesdeintegralistasquemorreram em conflitos de rua contra os que se opunham ao movimento, entre eles: Luiz Schroeder, Cae tano Spinelli, Jayme Guimarães e Nicola Rosica. Anauêl, jan. 1936, ano II, n.6, p.1.

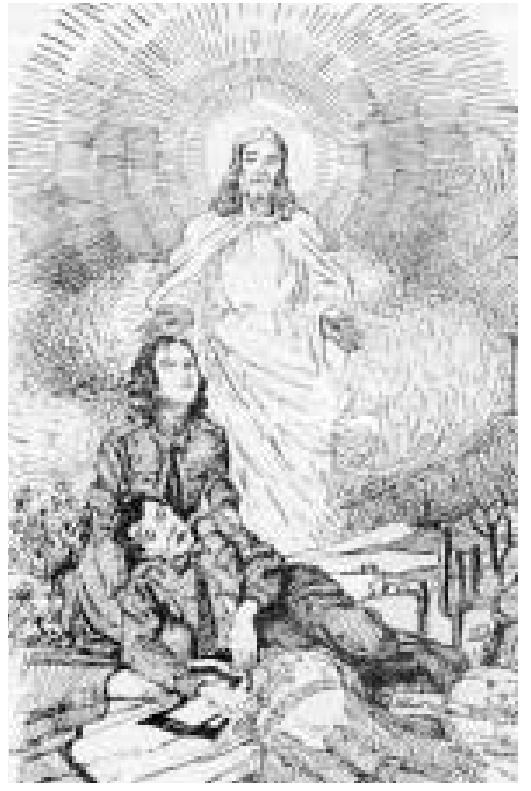

Figura 5 - Deus, pátria e família: D esenho procura descrever a morte de Luiz Schroeder, abraçado pela irmã. Vê-se a imagem de Jesus Cristo ao fundo, enquanto 0 morto segura as bandeiras do Brasil e da AIB. Anauê!, abr. 1936, ano II, n.9, p.16. 
a M ilícia do Além, porque no Integralismo ninguém morre: os que tombam a serviço da Pátria viverão eternamente no coração dos camisas-verdes" (Anauê! , maio 1935, ano I, n.2, p.9).

Como já expusemos, integralismo e cristianismo apareciam como doutrinas semelhantes nos escritos dos princi pais dirigentes do movimento enas imagens que eles produziam (Figura 6). Eurípides Cardoso de M enezes, mais uma vez, busca semelhanças bastante detal hadas entre os dois:

Zombavam os pagãos dos "fanáticos" seguidores do Cristo, o pobre justiçado como ladravaz ou homicida no al to do Calvário.

Escarneciam também os liberais- democratas e os comunistas dos que entusiasticamente se declararam seguidores da doutrina política de Plínio Salgado ... (Anauê!, dez. 1935, ano I, n.5, p.3)

É evidente que sendo o integralismo tão semelhante ao cristianismo não poderiam faltar analogias entre os seguidores mais próximos do Chefe Na-

\section{"O nosso nacionalismo está cheio de Deus"}

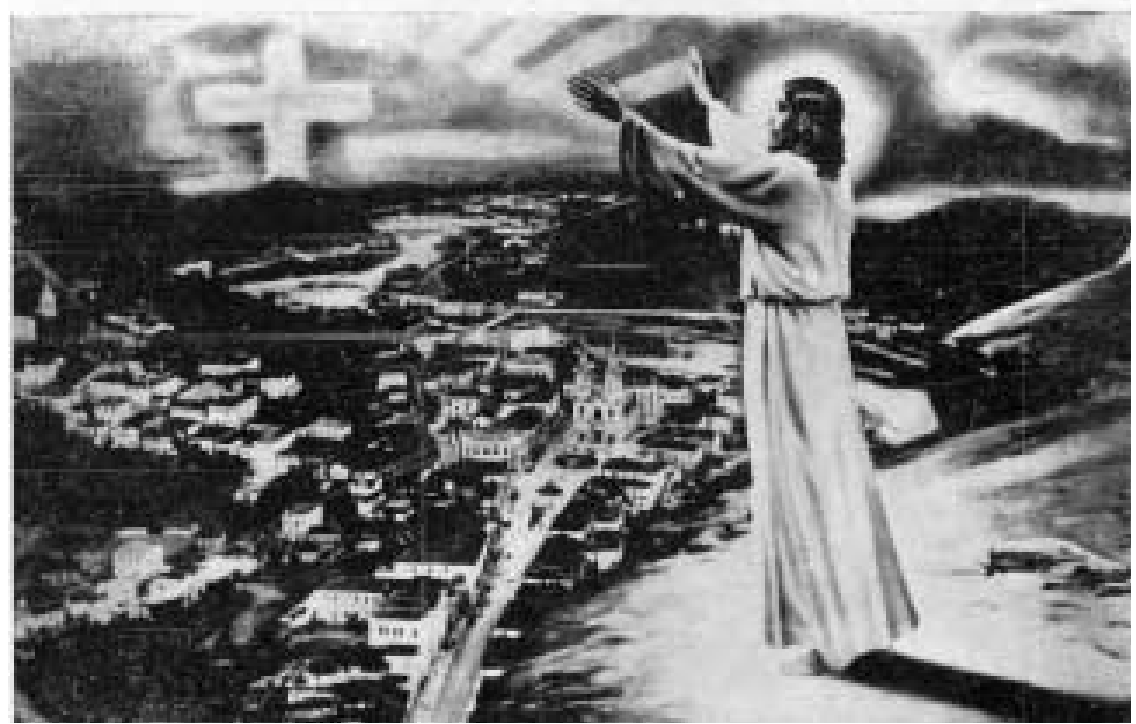

Figura 6 - Abençoados: Uma das imagens religiosas que tentam vincular Jesus Cristo à causa do nacional ismo integralista. A legenda que acompanha o texto afirma: "O Estado Integral é essencialmente o Estado que vem de Cristo, inspirando-se em Cristo, age por Cristo e vai para Cristo". Anauê!, nov. 1937, ano III, n.21, p.56. 
cional e os apóstolos de Cristo. Saulo (Paulo) de Tarso, por exemplo, antigo perseguidor dos cristãos, converte-se e torna-se, posteriormente, um deles:

0 integralismo também possui os seus Saulos: antigos perseguidores, ex-comunistas (como o grande M iguel Reale) que hoje vanguardeiam o M ovimento; outros que se preocupavam excessivamente com a glória do mundo, com o briIho na sociedade, com o fardão da Academia que possuíam ou desejavam possuir, percorrem agora os sertões do Brasil, com uma camisa verde modesta, proletária, cansando-se em estradas poeirentas, andando, como Gustavo Barroso, de segunda classe, em companhia de seus milicianos pela Zona da M ata de M inas Gerais. (p.4)

Esse texto de Eurípides de M enezes é de dezembro de 1935, portanto, anterior à já apresentada citação, de janeiro de 1936, no qual o mesmo autor compara o Chefe Nacional a Paulo de Tarso. N isso não há nenhuma incoerência, mas um projeto que colocava esses homens como figuras divinas, santos modernos, sacralizando, definitivamente, suas práticas políticas. M ais uma vez os conceitos religiosos são usados livremente para os interesses políticos. Isso é muito relevante, pois o movimento se propagandeia como uma forma de negação dos valores mundanos, uma Revolução do Espírito, como já se disse. 0 seu caráter transcendental fica evidente, na medida em que homens como M iguel Reale e Gustavo Barroso metamorfoseiam-se ao tomarem contato com a doutrina do sigma. Para o autor do artigo, Plínio não tinha “nenhum atributo divino" (p.5), mas tornava-se onipresente através da "i déia que ele tão admiravelmente encarna, e em nossos corações pelo amor que lhe vota mais de meio milhão de camisas-verdes" (p.5). Afinal de contas:

O integral ismo é hoje um só corpo, com um só Chefe, um só espirito, uma só alma! Em tudo parecido com o Cristianismo, contra o qual se organizou sempre o "ódio unido" de todos os maus; contra o qual se levantaram sempre as mais torpes calúnias; e que também foi considerado "vilipendio" pelo farisaísmo hipócrita e pela ignorância presumida de todos os tempos. (p.5)

M ovimento político e movimento religioso surgem como se fossem um só. Seu líder máximo, de tão perfeito, perde a sua essência humana: “O chefe não é uma pessoa esim a idéia" (Anauê!, jan. 1935, ano I, n.1).

Na Anauê!, como também em obras de autores filiados ao integralismo, a legitimação divina era uma presença constante em seus discursos, mas ela 
não estaria completa se o próprio Criador não tivesse aderido ao Chefe Nacional:

Deus é integralista, disse um dos nossos oradores!

Quem não experimentou os efeitos benéficos da transformação espiritual, de certo não compreenderá o sentido exato da revolução interna, porque integralismo é renúncia! ...

Cristo pregou o bem ea salvação e foi tido como louco e embusteiro e foi crucificado entre dois ladrões!

Obra de fariseus ...

E dessa casta o mundo está cheio ...

Já muitos camisas-verdes tombaram na luta pelo bem do Brasil. Outros ainda serão sacrificados, porém a idéia permanecerá e a vitória será certa, porque é o espiritualismo contra o materialismo, éo bem contra o mal.

Deus é integralista!

(Anauê!, dez. 1935, ano I, n.5, p.36)

Além de criar uma legitimação divina, os integralistas precisaram apelar para a história do Brasil e buscar os seus “antepassados” nos séculos anteriores.

\section{Determ inaÇões históricas: Plínio Salgado E A CONSTRUÇÃO DO GRANDE HOMEM}

Nem só de referências bíblicas podiam compor-se os discursos e as imagens em torno de Plínio Sal gado e da AIB. Na medida em que o movimento precisava aparecer como parte da natureza da sociedade brasileira, era necessário buscar nas raízes históricas do país justificativas para a sua existência e colocar o seu líder ao lado das figuras de vulto da história oficial. N esse processo seria fundamental encontrar em sua própria história de vida essas determinações. Em um artigo intitulado Reminiscências, na Anauê! de abril de 1937, o autor enxerga na cidade natal de Plínio, São Bento do Sapucaí, no interior de São Paulo, todos os fatores que explicassem o seu papel dentro da história brasileira. A análise etimológica de uma parte do nome de sua cidade é bastante sugestiva quanto a isso: “Corta a cidadezinha o rio Sapucaí, cujo nome, segundo al guns estudiosos, significa, em língua tupi, 'rio onde se espera', ou 'rio da espera', ou da 'esperança'... " (Anauê!, abr. 1937, ano III, n.14, p.11, grifos meus). 
Tudo parecia apontar para um futuro bastante promissor. Uma cidade que tem em seu nome a 'esperança', um menino, ali nascido, destinado à grandeza e futuro guia de um movimento que expressaria o que havia de melhor na nacionalidade. Em todas essas circunstâncias el e ia moldando o seu destino. Sua fotografia apresentada na reportagem (Figura 7) nada mais era do que a projeção de quem havia sido escolhido para liderar. No texto Plínio é construído como al guém que se destacava diante dos outros desde criança, pela sua origem (seu pai, Chagas Esteves Sal gado, era chefe local, e sua mãe, Ana Francisca Rennó Cortez, é apresentada pela reportagem como "senhora de grande ilustração", p.11), pelas suas posturas, pelas suas notas escolares, sendo um exemplo para os plinianos (o setor infanto-juvenil da AIB). Portanto, nessa construção vemos um conjunto de predeterminações em torno daquele que viria a ser o Chefe Nacional. Na verdade, esse artigo segue o mesmo padrão de grande parte dos escritos integralistas: exaltação de sua figura humana, o papel inovador do movimento, e os dois primeiros fatores surgindo no Brasil como um destino grandioso e surpreendente.

O pequeno Plínio servia como exemplo, logo, a sua figura deveria ser constantemente homenageada. Na fase adulta o seu destino se concretizaria. Por isso, era necessário colocá-lo ao lado dos grandes homens da história oficial. Em junho de 1937 Plínio Salgado era proclamado pelas Cortes do Sigma candidato à Presidência da República pela AIB. Daí em diante houve uma intensificação do trabalho de sua imagem como o grande homem. Nada mais revelador do que a capa de Anauê!, de outubro de 1937 (Figura 8), onde o Chefe Nacional tem seu rosto colocado ao lado do de Joaquim José da Silva Xavier, o Tiradentes. Ao mesmo tempo, tem-se também a impressão de que ele está brotando da face do mártir da Inconfidência, pois o desenho criado por Arthur Thompson, redator artístico da revista, mostra os rostos em perfil, estando o de Plínio um pouco à frente. Ao fundo vêem-se as bandeiras do movimento integralista, do Brasil e da Inconfidência. Na construção dessa capa todos os elementos que a compõem representam o mesmo objetivo: a exaltação dos val ores nacionais e Plínio Salgado como o redentor.

Deve-se observar que essa não foi a primeira vez que o periódico estabeleceu uma comparação entre os dois. Em março de 1936, no artigo "A volta de Tiradentes" lê-se um breve relato da vida do personagem, chamado ali de "gênio da raça", mostrando as suas origens e seu papel como inconfidente. No decorrer do escrito as intenções do autor vão sendo desvendadas ao destacar a visita que o Chefe Nacional fizera a M inas Gerais naquele mês (importante lembrar que essa é a mesma edição, já citada, que relata um encontro de es- 


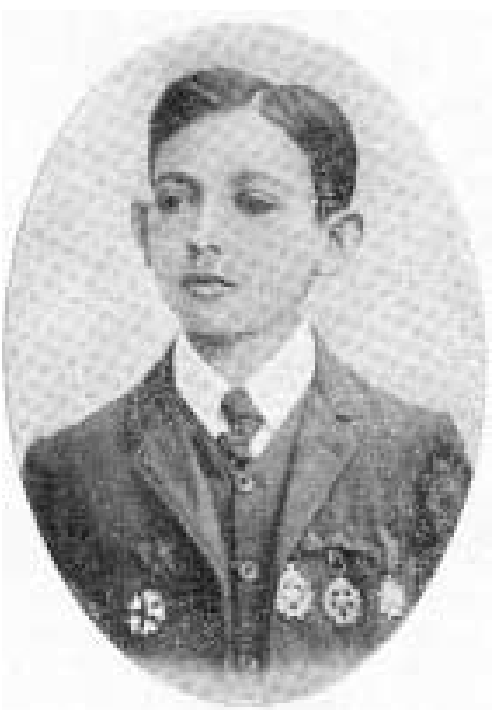

Figura 7 - 0 esperado: A imagem procura retratar os primeiros passos de um líder. Anauê!, abr. 1937, ano III, n.14, p.11.

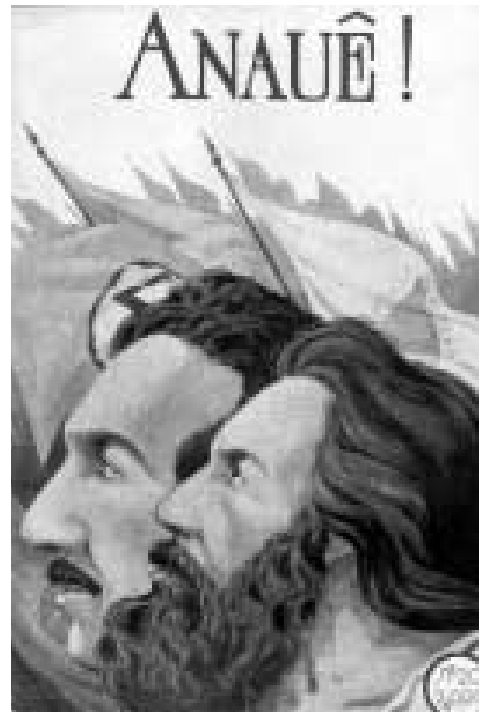

Figura 8 - Presente e passado: Candidato ao cargo máximo do país, Plínio Salgado tenta encarnar o espírito de um dos grandes mitos nacionais. Anauê!, out. 1937, ano III, n.20.

tudantes integralistas em São João Del Rei). À frente, no subtítulo “1936", observa-se a louvação àquele que o texto vê como o brasileiro mais brilhante daquele tempo, Plínio Salgado (comparado a Tiradentes), e ao integralismo (comparado à Inconfidência M ineira), o único movimento que poderia mudar os rumos da nação:

A Pátria, liberta de Portugal, caiu nas garras das forças judaicas do capitalismo. A sua riqueza formidável, a sua energia e o seu valor, tudo é consumido pelo estômago voraz dos inimigos do Brasil.

De novo surge a Inconfidência ... o Integralismo, o Sigma. Uma encarnação perfeita, mais forte ainda surge no cenário, diante de Deus e diante da Pátria. As aflições do passado, as pal pitações do presente e os ansei os do futuro se casam admiravelmente na camisa-verde.

O Grande Chefe veio dos sertões, conquistou o Norte e o Sul, o Centro, praias e metrópole, e agora volta ao seu lar antigo para entregar às gerações do futuro, 
na capital dos Inconfidentes, em S. J oão del Rei, a obra majestosa da construção da Pátria Integral.

Plínio Sal gado é o Tiradentes que volta às Alterosas depois de ter ligado todas as províncias ao coração da Pátria!

(Anauê!, mar. 1936, ano II, n.8, p.24)

Os paralelos entre Plínio Salgado eTiradentes eram apenas uns dos tantos que el es realizavam. N as várias edições de Anauêl o passado ressurge em formatos variados com o objetivo de legitimar historicamente o integralismo. Um dos paralel os mais recorrentes era estabelecido entre a coragem dos camisas-verdes e a luta contra a ocupação holandesa no Nordeste brasileiro no século XVII. Vê-se isso, de maneira cristalina, em uma conferência proferida na Paraíba por Ordival Gomes, ex-chefe do integralismo naquela província, onde se relatava, entre outras coisas, um encontro da AIB que havia ocorrido na capital pernambucana. A revista reproduziu essa fala em outubro de 1935.

A luta contra os holandeses era vista, por uma historiografia tradicional, como o instante de concepção da futura nação. Na reinvenção realizada pelos integralistas eles seriam os mais dignos herdeiros daqueles episódios, conseqüentemente os combatentes do período colonial eram apresentados como os "antigos e primeiros integralistas brasilei ros ..." (Anauêl, out. 1935, ano I, n.4, p.22). Nessas comparações o país na década de 1930 era vítima de uma nova invasão, cujo objetivo era torná-lo uma "colônia moscovita!!" (p.22). Os paralelos eram constantemente buscados com o intuito de justificar historicamente a existência do próprio movimento, além de fortalecer o anti-semitismo, o anti-comunismo e o anti-liberalismo de seus discursos. Por isso, os holandeses (invasores) de então seriam os comunistas ou, muitas vezes, os liberais-democratas. Os primeiros, vistos como agentes bolcheviques e influenciados por pensadores judeus; os segundos estavam abrindo o Brasil para o que os seguidores de Plínio Sal gado viam como o capitalismo judeu. N isso ambos são chamados de Calabares.

A composição étnica e social do movimento integralista era apresentada como plural (Figura 9), semel hante à dos que compunham a base da resistência aos holandeses. Ordival Gomes traça mais um paralelo entre os dois momentos históricos e vê o passado se materializar no presente:

Vimos, então, passar diante de nós o Índio Camarão, com seus Potiguares vaIorosos, Henrique Dias, o negro sublime, na frente de seus africanos, reviriliza- 


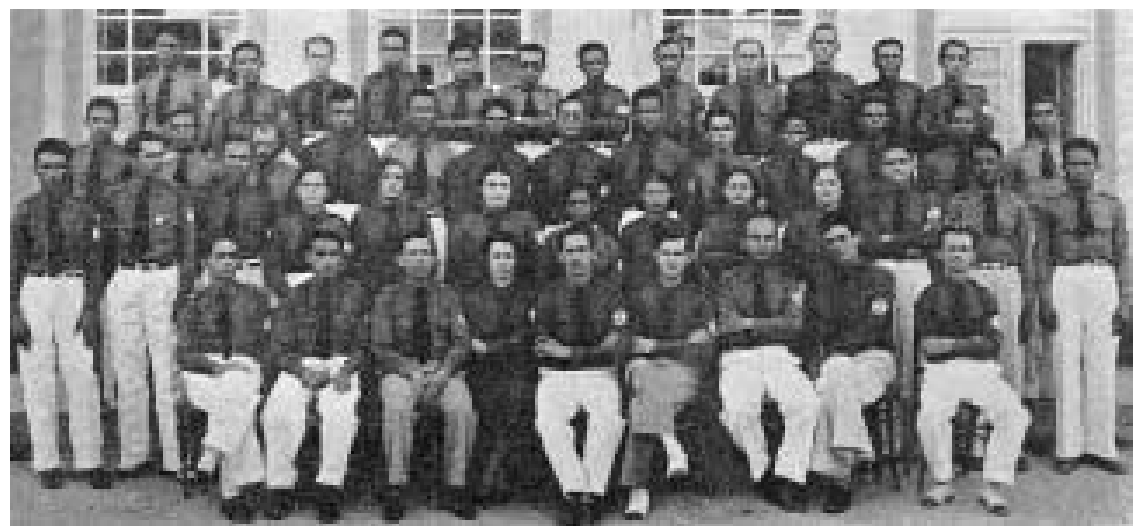

Figura 9 - Integralismo mestiço: Foto de integralistas alagoanos que ilustra a reportagem sobre a conferência O rdival Gomes. A imagem tentava mostrar o perfil pluriétnico do movimento. Anauê!, out. 1935, ano I, n.4, p.23.

dos, ao calor escaldante da sentimentabilidade brasileira; vimos AndréVidal de Negreiros, à frente de seus paraibanos, que sublimes e heróicos marchavam para o sacrifício ... (p.22)

Nessa construção o cenário da Batalha dos Guararapes ligava-se ao integralismo, significando momentos de lutas pela afirmação nacional, sendo apresentados como episódios irmanados, apesar das distâncias temporais que os separavam. Percebe-se a importância de se erigir uma ponte histórica entre esse passado heróico e o integralismo. U ma de suas intenções era anatemizar outras linhas de pensamento político, apresentando-as como alheias à realidade brasileira, especialmente a liberal-democracia e o comunismo (Figura 10). Quanto a este último, o conferencista afirma:

Cantai, comunistas, o hino rubro e vingativo da vossa Internacional, que nós cantamos os acordes sublimes, majestosos e eternos do hino que imortalizou 0 gênio de Francisco M anoel!

Espalhai o terror, o sangue, e cantai a vingança; que nós espalhamos a ordem ea disciplina e cantamos a epopéia ciclópica das bandeiras, e a insurreição majestática dos heróis de Guararapes.

Adorai Lenine: porque nós obedecemos a voz potente e brasilei ra de Plínio Salgado.

Sede internacionalistas; porque nós defendemos a todo transe os imperativos sociais da grande tradição brasileira. (p.59) 


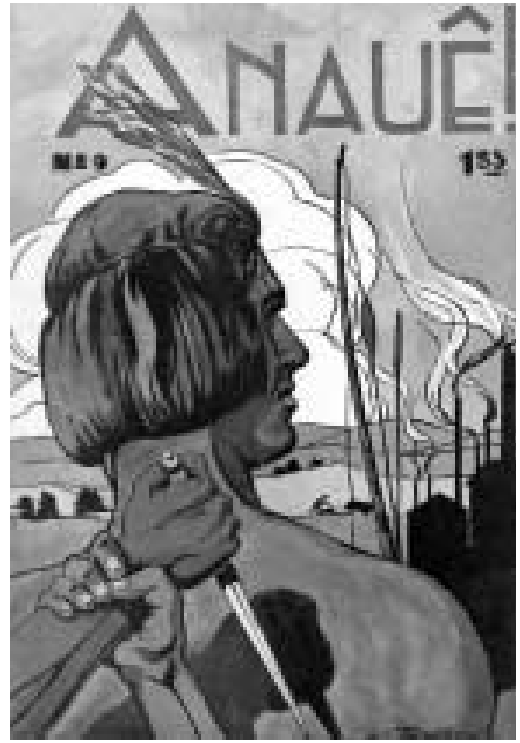

Figura 10 - Imagem didática: Numa referência clara à Intentona Comunista, o desenho de Arthur Thompson procura mostrar um índio (simbolizando o Brasil) olhando ao longe, enquanto uma mão vermelha (representando 0 comunismo) tenta apunhalá-lo traiçoeiramente. N esse momento surge uma mão verde (representan do o integralismo) que, heroicamente, detém a punhalada. Ao fundo observa-se um cenário que mistura aspectos rurais e urbanos. Anauê!, abr. 1936, ano II, n.9.

Em vários momentos os intelectuais integralistas buscavam uma valorização do homem brasileiro. U ma valorização que, contraditoriamente, possuía um certo grau de pessimismo. Em Despertemos a nação! Plínio Salgado fala sobre os brasileiros como um povo- criança: "Somos ainda um povo rudimentar. Q uase primário". ${ }^{21}$ Contudo, 0 autor via que esse povo muito jovem poderia utilizar isso a seu favor diante das desgastadas sociedades do Velho M undo.

H avia muitas construções discursivas que se realizavam em torno do índio, do negro, e dos vários tipos de mestiços, homens que formavam, juntamente com os brancos, o que el es denominavam de Raça Brasileira. Uma das que mais chama a aten ção diz respeito aos caboclos sertanejos do Nordeste. Encontram-se constantes referências aos episódios da Guerra de Canudos e aos seus combatentes sertanejos. Talvez a AIB tenha sido o primeiro movimento político a se referir a Canudos como um símbolo de resistência e heroísmo. Aqueles homens que lutaram contra quatro expedições também poderiam ser vistos como integralistas antes do integralismo. Os articulistas de Anauê! produziram textos bastante curiosos sobre isso:

Bahia, berço da nacionalidade, que viu o Brasil nascer, contempla agora o seu maravilhoso renascimento. Onde se real izou a primeira eucaristia, se realiza hoje estoutra Eucaristia, a Eucaristia da Pátria N ova, consubstanciada nas legiões cristãs do Sigma. 
Itabuna, Ilhéus, Nazaré, Petrolina, Juazeiro, Jequié, Cachoeira - enfim todo o sertão baiano se levanta, como um só homem, pronto, se necessário, a reproduzir a memorável campanha de Canudos, em defesa da honra, da soberania e da Pátria vilipendiada.

(Anauê!, maio 1935, ano I, n.2, p.37)

A passagem é um tanto confusa ao, por exemplo, referir-se a todas essas regiões baianas como sertão, ou ainda, ao citar a cidade de Petrolina como parte do sertão baiano, sendo ela uma cidade pernambucana. M as deixando de lado as imprecisões geográficas, o que chama a atenção no texto é o fato de seu autor citar Canudos. Existem dados bastante concretos sobre o crescimento do integralismo no interior da Bahia. ${ }^{22}$ Isso levou o autor do texto citado a ver esse fenômeno como se fosse uma retomada da Campanha de Canudos. Muito provavelmente ele se identificava ao lado dos que entraram em combate em defesa de Antônio Conselheiro e não do exército nacional. Pode-se constatar essa questão em outros escritos, nos quais a admiração pelos sertanejos é afirmada de maneira bastante explícita. Um dos importantes pensadores da AIB, o ComandanteVictor Pujol, diz do homem do sertão:

N enhum outro exemplar da nossa sub-raça caracteriza melhor o tipo brasileiro que o filho do Nordeste, sobretudo o caboclo rústico do sertão. 0 caboclo nordestino possui todas as virtudes que só a grandiosidade e a aspereza da Terra são capazes de desenvolver. É inteligente e arguto, revelando quase sempre uma sensibilidade e um senso das realidades superiores aos do homem civilizado.

(Anauê!, jan. 1936, ano II, n.6, p.8)

Nas linhas seguintes Pujol fala sobre o sofrimento desse homem do sertão diante da seca e da fome, cita a importância da obra-prima de Euclides da Cunha para entender aquela realidade e fecha a análise de maneira bastante otimista: "Com esses caboclos construiremos um dia a grande Pátria Brasileira" (p.8). Ilustrando o escrito de Victor Pujol há uma das fotos mais interessantes de todos os números de Anauê! (Figura 11). Ela tem o título de Congresso da Bahia, uma referência ao encontro integralista ocorrido ali em 1935, e nela aparecem vários homens vestidos com o uniforme integralista. A legenda informa: "Os sertanejos de Canudos se abalaram até Salvador para ouvir a palavra empolgante do grande Chefe" (p.8).

As idéias nativistas foram uma das principais características do movimento integralista. As culturas indígenas eram vistas como parte essencial da 


\section{Congresso da Bahia}

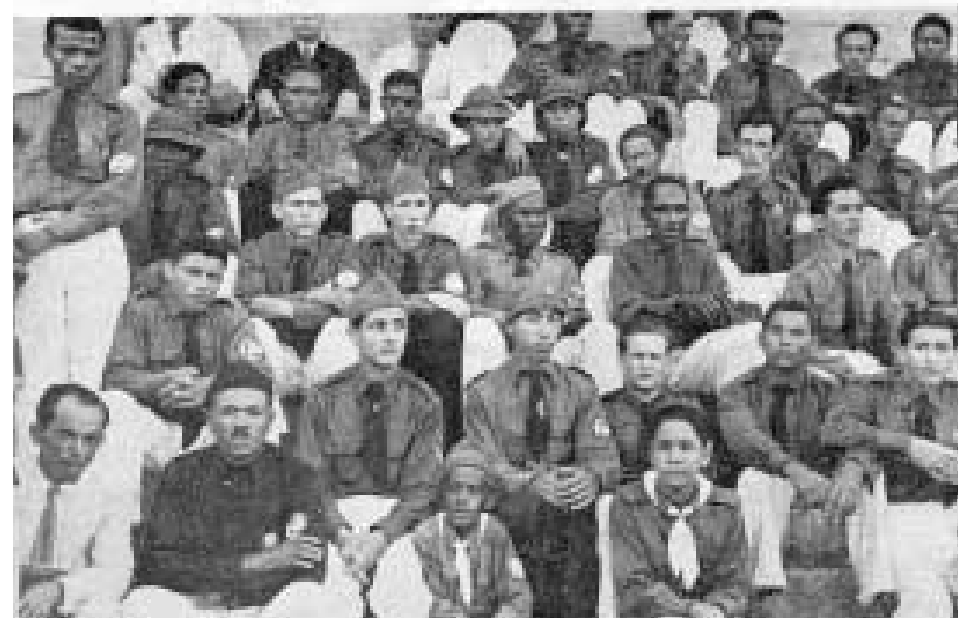

Figura 11 - Entre Antônio Conselheiro ePlínio Salgado: Foto retrata partici pação dehomens identificados como sertanejos de Canudos em um congresso da AIB em Salvador. Anauê!, jan. 1936, ano II, n.6, p.8.

formação brasileira. Plínio Salgado e outros membros da AIB pertenceram ou foram influenciados por diferentes correntes do modernismo. Ao mesmo tempo, houve uma espécie de resgate do romantismo, pois, na reinvenção da nação e na nova independência que o integralismo promoveria, o índio seria o símbolo brasileiro por excelência. Em uma reportagem que relata o papel de Paulo Eleutério, chefe provincial do Amazonas na difusão do ideário do sigma naquela região, vê-se que além de mostrar o crescimento da AIB nas cidades houve um esforço em divulgar o integralismo entre al gumas tribos amazonenses. Como se fossem novos catequizadores, esses integralistas viam a necessidade de absorver os indígenas à vida nacional e lhes ensinar princípios cívicos. A foto que ilustra a reportagem (aliás, muito bem construída) mostra em destaque três mulheres indígenas fazendo a saudação romana, tendo ao fundo a bandeira nacional (Figura 12). Ao lado da imagem 0 articulista descreve isso como um feito da pureza do integralismo:

PLÍNIO SALGADO, que passou noites a fio a estudar a língua tupi, que penetrou nas profundezas da alma brasileira, que soube fazer-se o interprete da Raça, recebe agora, comovido evencedor, os "anauês" mais puros, mais sublimes, 
mais brasileiros: os "anauês" de 5.000 índios integralistas que o heroísmo de osé Guiomar foi evangelizar nas florestas do Amazonas.

(Anauê!, maio 1935, ano I, n.2, p.15, grifos meus)

Dentro do que vimos até o momento, a presença da palavra evangelizar e de outra com conotação religiosa como puro não nos causa espanto. Podese até tentar buscar al gumas similaridades com evangelizações ocorridas no passado colonial . Entretanto, essa, de heróis de então como o citado J oséGuiomar, possuía um dado novo, não menos cruel, pois seu objetivo era mostrar, paternalmente, aos índios que eles eram índios e que sua originalidade os fazia a pedra fundadora da nação.

Pelo que mostram as fotos das manifestações públicas em diferentes regiões do Brasil e testemunhos da época, havia uma razoável presença de negros dentro do movimento. Dentre tantos, um que fora muito conhecido duas décadas antes do surgimento da AIB: João Cândido, líder da Revolta da Chibata, de 1910. Na maior parte dos artigos da revista Anauê! que têm o negro como objeto de análise há uma ênfase na sua participação como o elemento central do processo de escravidão. A vítima e, ao mesmo tempo, o rebelde que lutou contra o cativeiro. 0 discurso integralista em torno do negro sempre

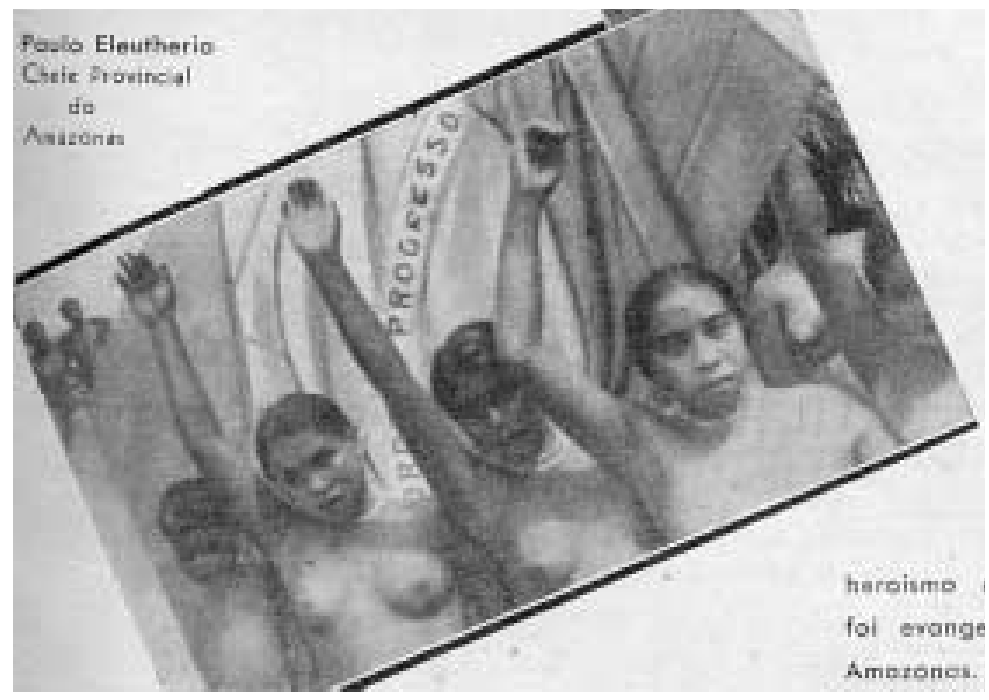

Figura 12 - Um anauêoriginalíssi mo: Í ndias amazonenses posam com a bandeira brasileira ao fundo. Anauê!, maio 1935, ano I, n.2, p.15. 
revela um paternalismo no qual o Chefe $\mathrm{N}$ acional exerceria um papel de libertador, pois a doutrina do sigma seria tão importante quanto a Lei Áurea (Figura 13). Em uma reportagem sobre o Treze de Maio, na Anauê! de junho de 1937, há uma reflexão sobre a importância de tal data para o Brasil e da contribuição do negro para a formação nacional. Percebe-se, em determinada parte, uma crítica acerba sobre as influências do pensamento do Conde Gobineau (o autor errou na grafia ao escrever Gabineau) sobre a elite intelectual brasileira no Império e em parte da República: "Felizmente nos livramos daquela mentalidade livresca e raffiné que via no negro um motivo de vergonha nacional e repetia, como papagaio, a teoria da inferioridade da nossa raça elaborada pelos despeitados Gabineau [sic] de todos os quadrantes" (Anauê!, jun. 1937, ano III, n.16, p.25).

Nas linhas seguintes há elogios aos estudos que vinham revelando vários aspectos das culturas africanas presentes no Brasil e como isso era importante para o autoconhecimento nacional. Como não poderia faltar uma inserção

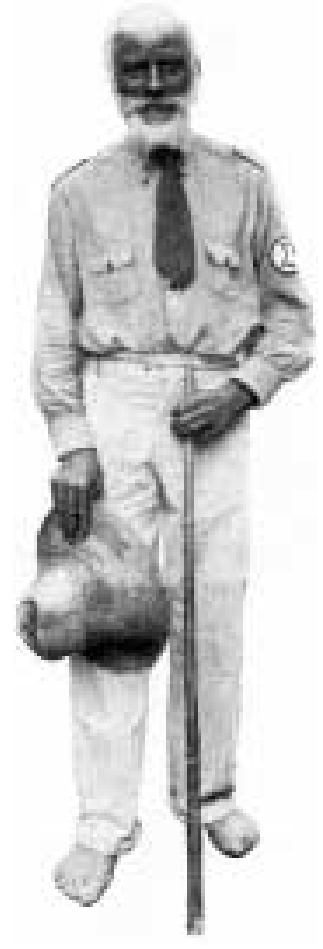

Figura 13 - Propagandeando a igualdade: U m homem idoso, que viveu no tempo da escravidão, trajando um uniforme integralista em M inas Gerias. Anauê!, abr. 1937, ano III, n.14, p.23. 
do integralismo, o texto é finalizado com um conjunto de promessas bastante amplas, dando a idéia de que os negros poderiam esperar muito da AIB:

N esta página, pois, dedicada ao 13 de maio, queremos acentuar o profundo interesse que empolga os estudiosos integralistas pelo problema do negro na sociedade brasileira e queremos também homenagea-lo - nos negros operários, soldados de polícia, marinheiros, estivadores, pescadores, soldados do exército, trabalhadores rurais, que, na hora presente, vivem conosco a esperança de um grande Brasil.

(Anauê!, jun. 1937, ano III, n.16, p.25)

No discurso integralista a história deveria formar o ser humano e o cidadão. Diante de tal objetivo era necessário, desde a mais tenra idade, incutir os valores patrióticos nos brasileiros. Em um artigo de nome Sublime missão Floriano Thompson Esteves, membro da Secretaria Nacional de Organização Política, fala sobre a importância do papel da mulher dentro da AIB ea função desta na educação dos filhos. Para o autor do texto as crianças deveriam aprender a história do país ainda no berço:

Para tema das vossas canções de embalo escolhereis os gestos dos nossos heróis. As histórias dos nossos fil hos serão cal cadas nos rasgos de heroísmo da nossa gente; os feitos de Caxias, ou de O sório, Tamandaré e tantos outros, os exemplos incomparáveis de Anchieta, os rasgos de heroísmo do nosso bandeirante ou a epopéia de atitudes guerreiras como a Retirada da Laguna. Serão destes e de tantos outros feitos organizadas to das as nossas histórias infantis. E, então tereis criado o verdadeiro amor pelo Brasil. D eixaremos e renegaremos para sempre as histórias da Carochinha, os contos de fada ou as histórias do bicho papão que incutindo o terror, despertam na criança o medo ea insegurança em si próprio.

Vede, mulher do meu Brasil, como será incomparável a vossa obra!

(Anauê!, jan. 1935, ano I, n.1, p.23)

A formação dos corações e das mentes das crianças por meio de uma doutrinação sistemática, tendo os grandes fatos e os grandes homens como modelos a serem seguidos, era al go significativo dentro da estratégia dos integralistas exposta em Anauê!. Recriar o passado, buscar uma identificação entre Plínio Sal gado e os mitos da história nacional, consolidando o integralismo como um capítulo de mudança na vida do país. Tudo isso germinaria na alma dos plinianos (Figuras 14 e 15). 


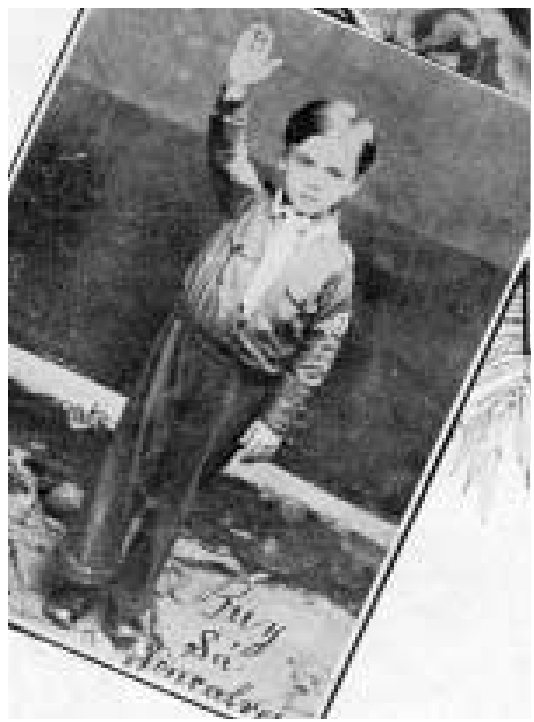

Figura 14 - Doutrinação infantil 1: Pliniano posa para foto fazendo a saudação romana. Anauê!, set. 1936, ano II, n.12, p.16.

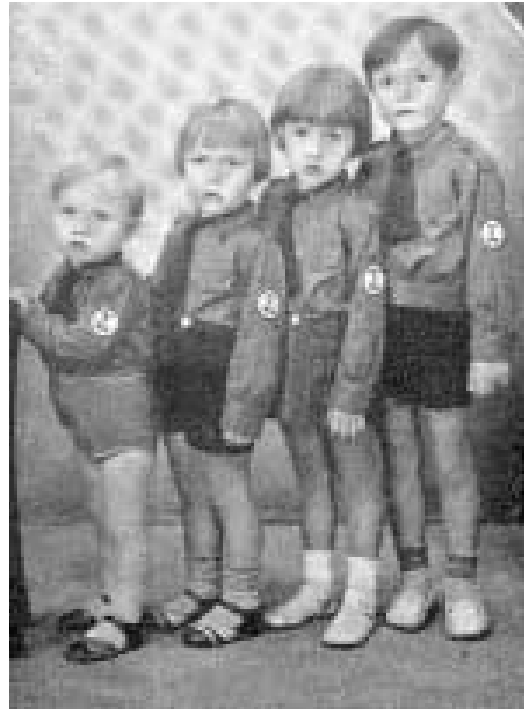

Figura 15 - Doutrinação infantil 2: Plinianos formam uma "escadinha". Anauê!, jul. 1937, ano III, n.17, p.49.

Não se vê nisso apenas teoria. Era necessário repensar a história e agir dentro dela. Há, sem dúvida, um conjunto de ações nas quais a AIB comportou-se como um movimento político reacionário, filho de sua época. 0 discurso nacionalista, anti-semita, anti-comunista e anti-liberal eram evidentes. Porém, no que diz respeito a esse agrupamento político é sempre perigoso apresentá-lo como se tivesse sido uma mera sucursal dos movimentos de extrema-direita europeus nos trópicos, como se tivesse seguido uma cartilha. Como se afirmou no início deste artigo, há um conjunto de controvérsias historiográficas sobre a natureza do movimento. Na obra de A. Tenório D'Albuquerque, Integralismo, nazismo e fascismo: estudos comparativos, cuja primeira edição éde 1937, o autor nega que sejam movimentos idênticos procurando diferenciar cada um deles, mostrando as características nacionais de onde se originaram. ${ }^{23}$ Entretanto, isso não significa que não possuíssem afinidades; 0 autor denomina os três de reações nacionalistas (p.45).

Porém, se voltarmos, mais uma vez, para a percepção semiótica desses diferentes fenômenos políticos, a sua natu reza comum salta aos olhos. Uniforme de campanha, criação de símbolos para serem cultuados junto com a bandeira nacional, propaganda, culto ao líder e, logicamente, uma reinven- 
ção do passado histórico. No prefácio do livro de José Chasin, Antonio Candido lamenta o fato de o autor não ter dado a devida atenção a esses fatores e mostra como eles são relevantes:

Defato, a Ação Integralista Brasileira possuía todos os elementos de caracterização externa do fascismo, como a camisa-uniforme, nascida da camiccia nera de Mussolini, que nele era verde (como nos congêneres romeno e húngaro), tendo sido parda no nazismo, preta nos fascistas tchecos e ingleses, azul nos irlandeses e nos portugueses de Rolão Preto; e até dourada num agrupamento mexicano aparentado. $\mathrm{Ou}$, ainda, o signo de conotação meio mística: fascio littorio, svástica, cruz de fechas, tocha e, no Brasil, o sigma somatório. O u, também, a saudação romana, comum a todas as modalidades e que entre nós passou por um processo revelador de assimilação, identificando-se à saudação indígena de paz com o brado 'Anauê'. Resultou uma saudação nacional, peculiar, reveladora do indianismo que sempre reponta em nossos diferentes nacionalismos como busca do timbre diferenciador; mas que nem por isso deixa de ser manifestação do sistema simbólico do fascismo, geral. ${ }^{24}$

Portanto, por mais que o integralismo estivesse en raizado nas tradições políticas brasileiras, como insiste Chasin ou como querem as obras de contemporâneos que pertenceram às suas fileiras, ${ }^{25}$ ele esteve, ao mesmo tempo, em sintonia com a estética política de movimentos que surgiram como restauradores da ordem e do orgulho nacional do outro lado do oceano. Como a estética é parte importante da ética de qualquer grupo humano, a AIB, sem dúvida nenhuma, teve, não só nos seus aspectos exteriores, mas também nos interiores, elementos muito concretos do fascismo. 0 integralismo foi um movimento que conseguiu ter um espírito próprio, que usou habilmente fatores de uma sólida cultura autoritária existente no país, mas que, ao mesmo tempo, esteve sujeito às influências globais de sua época (Figuras 16 e 17). Diante disso, nada melhor do que um competente meio de divulgação de idéias e imagens. A Anauê! conseguiu cumprir esse papel.

\section{CONCLUSÃO}

O espetáculo não é um conjunto de imagens, mas uma relação social entre pessoas, mediada por imagens. ${ }^{26}$ 


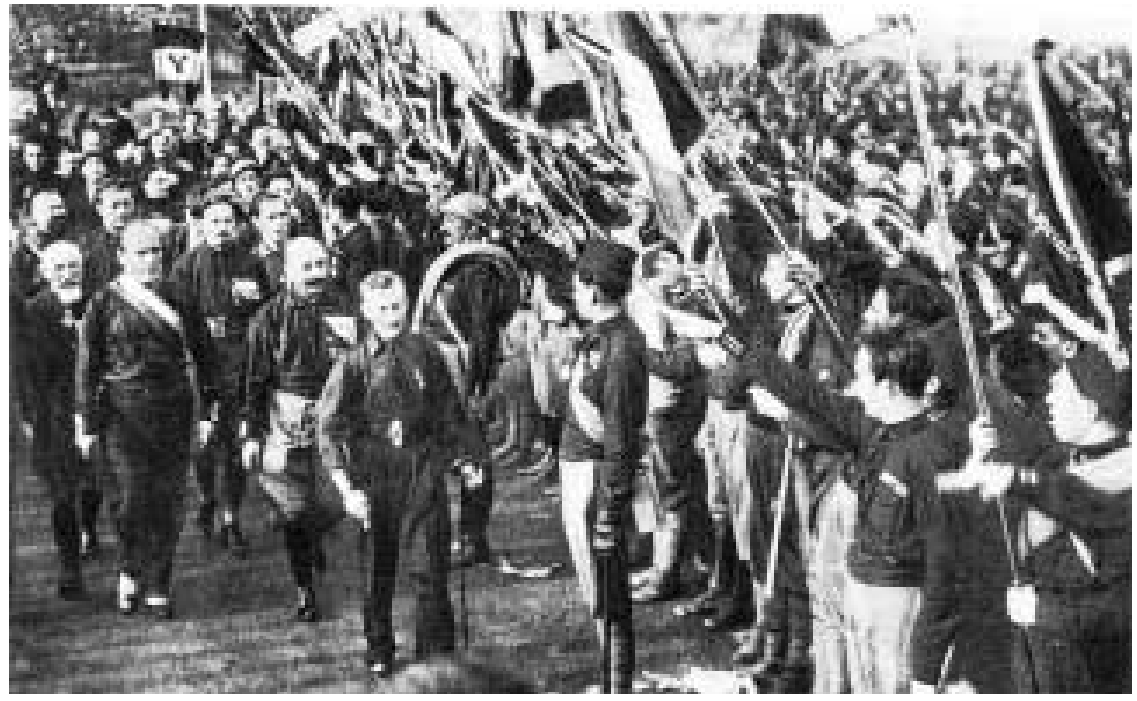

Figura 16 - Estética fascista 1: Benito M ussolini é saudado por seus partidários em N ápoles, Sarfatti, M argherita. D ux: Edizionellustrada. Milano: Mondadori, 1934, p.170.

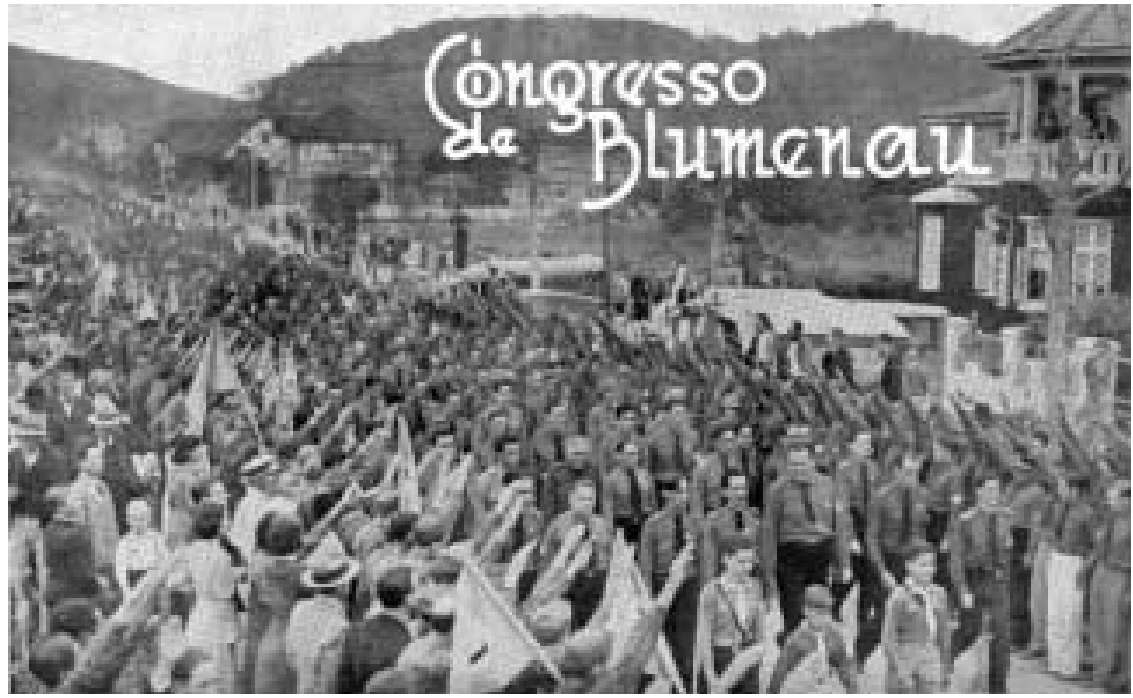

Figura 17 - Estética fascista 2: Plínio Salgado é saudado por seus partidários, em Blumenau. Anauê!, dez. 1935, ano I, n.5, p.25. 
Esse é um dos aforismos do livro de Guy Debord A sociedade do espetáculo, lançado em novembro de 1967. 0 autor procura entender como naquela fase da modernidade as imagens ganhavam um papel central no processo de acumulação de capitais e, conseqüentemente, na própria forma de se estruturar o poder político. 0 predomínio da imagem trazia tons espetaculares a esse mundo, em seus diferentes regimes políticos. A ação política, a percepção do cotidiano e a própria noção de história foram sendo lentamente alteradas dentro desse processo: "A realidade do tempo foi substituída pela publicidade do tempo" (p.106). Debord percebe que esse processo foi se desenvolvendo ao longo da modernidade, e, na época em que ele escreveu sua obra (anos 60), tudo já estava plenamente cristalizado.

Ao pensar em qualquer movimento político do século XX deve-se levar em conta qual foi a sua produção de imagens ao longo do seu processo de formação, da sua luta e da sua chegada ao poder, quando isso tenha ocorrido. Numa época em que os avanços tecnológicos proporcionaram uma maior capacidade de produção de imagens, em queos avanços da comunicação trouxeram a possibilidade de uma diminuição significativa das dimensões do globo, grupos políticos de várias tendências tiveram na propaganda uma aliada central. Somada a tudo isso, houve uma entrada maciça de pessoas no cenário político. Nas democracias, nas ditaduras, nos totalitarismos era necessário lidar com as massas, numa época em que ler imagens passava a ser algo central no mundo urbano e moderno, seja para consumir, votar ou venerar um líder.

A revista Anauê!, um dos principais órgãos de divulgação do pensamento da AIB, materializa todas essas características. Ao analisarmos o seu conteúdo não vemos o que a totalidade de seus correligionários pensavam, mas sim o que seus principais dirigentes queriam propagandear sobre o movimento. Temos de levar em conta que a revista tinha sua sede no Rio de Janeiro, estando, muitas vezes, distante das amplas real idades que tentava representar. A pesar disso, seus líderes sabiam que estavam em um país continental, com grandes diferenças, e faziam o possível para atingir um público amplo, com imagens das ações integral istas do Amazonas a M inas Gerais, dos pampas gaúchos ao sertão nordestino, ou com textos de integral istas que estavam fora do centro do país.

O que impressiona nas páginas da revista é a dimensão publicitária de seus elaboradores - característica comum de outros periódicos da AIB. Apesar da crítica tão veemente ao capitalismo-liberal, a presença de produtos de consumo como anunciantes em suas páginas é al go que chama atenção: Ba- 
yer, Biscoitos Aymoré, Casa Bancária Nacional do Comércio eIndustria, Pirelli e os refrigeradores Westinghouse, entre outros. H avia apelos interessantes:

\section{Sr. Comerciante!}

Como estais lendo estas linhas, milhares doutras pessoas também o fazem em todas as Províncias do Brasil. Neste lugar devia estar um anúncio de vossa casa, não é verdade?

(Anauêl, out. 1935, ano I, n.4, p.16)

O utros apelos eram permeados pelo bom humor, apesar da seriedade que a revista tentava passar para os seus leitores: “O melhor presente para um comunista, um indiferente ou um simpatizante é uma assinatura anual da revista Anauêl" (p.32).

Ler a revista Anauê! é estar diante de um fragmento de uma época que marca, com toda certeza, uma mudança na qual a política ea propaganda passam a andar de mãos dadas. Época em que o método de divulgação de uma idéia, de um projeto e de uma liderança deveria ser transmitido às massas em uma linguagem semelhante à de um produto de consumo, em que o discurso emotivo deveria predominar. Nesse processo, no qual nós ainda vivemos, resta saber quem sobrevirá - a política ou a propaganda.

\section{NOTAS}

${ }^{1}$ M estre em História e Cultura pela Universidade Estadual Paulista (Unesp - FHDSS), professor de História da América na Universidade Estadual de Santa Cruz (UESC). Autor de Antônio Conselheiro: a fronteira entre a civilização e a barbárie. São Paulo: Annablume, 2001 (Coleção Estudos Universitários, 153).E-mail: rogerhist@uol.com.br

${ }^{2}$ LIM A BARRETO. Tristefim de Policarpo Q uaresma. 19.ed. São Paulo: Ática, 1998, p.37.

${ }^{3}$ AREN DT, H . A condição humana. Trad. Roberto Raposo. 7.ed. Rio de Janeiro: Forense Universitária, 1995, p.17.

${ }^{4}$ GEERTZ, C. A interpretação das culturas. Rio de Janeiro: LTC, s.d., p.4.

${ }^{5}$ BALAN DIER, G. 0 poder em cena. Trad. Luiz Tupy Caldas de M oura. Brasília: Ed. UnB, 1982 (Coleção Pensamento Político), p.5.

${ }^{6}$ Em: TRINDADE, H. Integralismo: 0 fascismo brasileiro na década de 30. São Paulo/Rio de Janeiro: Difel, 1979 e CHASI N, J. 0 integralismo de Plínio Salgado: forma de regressividade no capitalismo hiper-tardio. São Paulo: Livr. Ed. Ciências Humanas, 1978. 0 primeiro procura uma similaridade entre as manifestações do fascismo na Europa e a experiên- 
cia integralista no Brasil. Para isso, analisa artigos de periódicos da AIB, vê as características de massa que estiveram presentes naquela agremiação política e realiza um perfil dos seus princi pais quadros. Já o segundo descarta as possibilidades de a AIB ser fascista. Para ele, esse fenômeno político caracterizou as nações européias que tiveram uma unificação nacional tardia, uma industrialização acelerada e que foram malsucedidas na corrida imperialista. Por essa razão tinham na expansão territorial um ponto de honra nacional. Nessas características I tália eA lemanha se enquadrariam mel hor. Para ele, o integralismo é uma manifestação política que reflete os problemas brasileiros.

${ }^{7}$ Existem vários livros escritos por importantes nomes do movimento integralista, nos quais se destacam as diferenças em relação ao nazismo eao fascismo. 0 ComandanteVictor Pujol afirma: "O Integralismo sendo um movimento profundamente nacionalista e com finalidade no Estado Integral, tem pontos de contato com o fascismo e o hitlerismo, mas se distingue destes pelo seu caráter eminentemente brasileiro. É um movimento original, com uma filosofia própria. 0 Estado Fascista foi estruturado dentro de tradições históricas e de condições econômicas diferentes das nossas. Se, por um lado, o integral ismo aceita o organismo político, econômico e ético do Estado M oderno ea sua economia dirigida, por outro sustenta a forma republicana federativa, com centralização política e descentral ização administrativa dos M unicípios. Caracteriza-se ainda pelo seu modo de representação política (junto à profissional), pela integração dos grupos profissionais e pela liberdade do trabalhador no sindicato e exclusão de toda e qualquer tirania racial ou espiritual. Não temos no Brasil os problemas do anarco-sindicalista ou de raça como tiveram a Itália e a Alemanha, que se viram forçadas a limitar momentaneamente os direitos individuais". PUJO L, V. Rumo ao Sigma. 3.ed. Rio de Janeiro: Livr. H . Antunes, 1936, p.160-1.

${ }^{8} \mathrm{Na}$ introdução de Despertemos a nação! Plínio Salgado revelou a importância que os ares da Europa tiveram no seu pensamento: “Em 1930, segui para a Europa. O período de 1927 a 1930 revelou-me a impossi bilidade de fazer algo de novo dentro dos vel hos quadros partidários e sociais do país. Os que se interessam, com boa ou má intenção, pela minha vida, deverão estudá-la na minha obra jornalística e parlamentar daquele tempo. Estava eu em 30, convencido da urgência de uma revolução do pensamento nacional, da consciência das massas brasileiras. M eus amigos, que me levaram até à estação ( e entre el es M enotti del Picchia e M ário Graciotti) perguntaram-me em que estado de espírito eu partia. 'Voltarei para fazer a nossa revolução', respondi-Ihes. Depois de percorrer 14 países, como preceptor de um moço de uma família paulista, que me abriu um crédito suficiente para vultuosas despesas, terminei em Paris 0 Esperado e esbocei o manifesto que pretendia lançar às novas gerações brasileiras. Vira a renovação política da Turquia, o fascismo na Itália, lera uma vasta literatura comunista que circulará em Paris, estudara a social democracia alemã, examinara a pequenina Bélgica, meditara no Egito, sobre o imperial ismo inglês, observara a anarquia dos espíritos na Espanha e a nova ordem em Portugal, e tudo me demonstrava a morte de uma civilização, o advento de uma nova etapa humana". SALGADO, P. O bras completas, v.X. São Paulo: Ed. das Américas, 1955, p.19-20. 
${ }^{9}$ Segundo Gustavo Barroso a palavra anauê seria uma junção de diferentes formas de saudações existes na língua tupi. BARROSO, G. 0 que o integralista deve saber. Rio de Janeiro: Civilização Brasileira, 1935, p.149-52.

${ }^{10}$ Faz-se necessário explicar que em março de 1932, em São Paulo, era fundada a Sociedade de Estudos Políticos (SEP), que tinha por finalidade o desenvolvimento de uma nova mentalidade e a discussão de idéias para o país. Esse grupo era formado por vários intelectuais paulistas que se identificaram com o discurso de Plínio Sal gado. Em maio do mesmo ano, Plínio propõe a criação de uma seção da SEP que teria o objetivo de transmitir em larga escala as idéi as discutidas no grupo. Essa seção ganhou o nome de Ação Integralista Brasileira (AIB). Os acontecimentos da Revolução Paulista impossibilitaram a divulgação do manifesto onde estariam colocadas as diretrizes do movimento. Com o término da Revolução houve a possi bilidade de divulgação do documento que ficaria conhecido como o M anifesto de 0 utubro, marco fundador da AIB. A partir daí o integral ismo ganha uma amplitude maior, apresentando-se como portador de uma nova ordem política, social e econômica, mantendo as características de um movimento cultural, mas não ficando restrito a um grupo de intelectuais e sim pretendendo atingir as massas. Ver: SALGADO, P. Enciclopédia do Integralismo: o integralismo na vida brasileira, v.l. Rio de Janeiro: GRD, s.d., p.141-51.

${ }^{11}$ Cito, como exemplo, três passagens de textos de Plínio Salgado que expressam uma escrita emocional e outras que fazem uma clara discriminação de classe entre seus leitores. Em Geografia sentimental ele escreve: "Brasileiros de todas as Províncias, de todos os partidos, de todas as crenças, de todas as cidades, povoados e sertões! Estelivro foi escrito devagar e com amor. Pus nele todo meu afeto pelo Brasil. É a minha impressão da Grande Pátria, colhida desde a infância. Esta nação querida não pode ser descrita, para os corações, num relatório. A sua geografia deve constituir um poema. A interpretação do sentimento nacional" (grifos meus). 0 bras completas, cit., v.IV, 2.ed., 1957, p.11. Em outro exemplo, Plínio deixa claro a quem estava destinando o seu livro 0 que é integralismo?: “Escrevo para o meu povo, numa hora de confusão e de duvidas, tanto nacionais como universais, e todo meu desejo é o tornar acessível aos mais simples o pensamento quejá penetrou as classes ilustradas do País" (grifos meus). O bras completas, v.IX, 1955, p.17. Por último, em uma passagem inicial de Psicologia da revolução o exclusivismo desse livro fica evidente: "Este não éum livro para o povo, mas para os que pretendem influir nos destinos do povo. Aos políticos e aos intelectuais é que me dirijo" (grifos meus). O bras completas, v.VII, 1955, p.9..Em outros autores integralistas notam-se essas mesmas distinções entre os seus diversos públicos.

${ }^{12}$ NIETZSCHE, F. W. Além do bem e do mal: prelúdio de uma filosofia do futuro. Trad. Paulo César de Souza. São Paulo: Companhia das Letras, 2000, p.101.

${ }^{13}$ ORTEGA Y GASSET, J. A rebelião das massas. Trad. Herrera Filho. 2.ed. Rio de Janeiro: Livro Ibero-americano, 1962, p.59. 
${ }^{14}$ AREN DT, H. Origens do totalitarismo: anti-semitismo, imperialismo e totalitarismo. Trad. Roberto Raposo. São Paulo: Companhia das Letras, 2000, p.361.

${ }^{15}$ TOCQUEVILLE, A. de. A democracia na América: leis e costumes (De certas leis e certos costumes políticos que foram sugeridos aos americanos por seu estado democrático). Trad. Eduardo Brandão. São Paulo: Martins Fontes, 1998, p.289-323.

${ }^{16}$ M ARX, K. 018 Brumário e Cartas a Kugelmann. Trad. Leandro Konder e Renato Guimarães. São Paulo: Paz e Terra, 2002, p.78-9.

${ }^{17}$ É importante observar que Plínio Salgado faz inúmeras críticas ao messianismo existente na cultura política brasileira. Em D espertemos a nação! ele afirma: “O descontentamento popular manifesta-se na eterna esperança de um M essias salvador. Os heróis da revolução estavam destruídos. 0 misticismo nacional apela para o Acaso, para algum personagem misto de Antônio Consel heiro, Padre Cícero e Floriano". SALGADO, P. O bras completas, cit, v.X. p.111. Ao mesmo tempo, o autor vê a possibilidade de transformar essa característica em um elemento de elevação nacional: "Esse povo ainda virá a ser al guma coisa muito grande e muito séria na Humanidade. Ao seu messianismo que se polariza na figura legendária do 'herói', respondamos com um messianismo fundado na realidade, nos fatos positivos do processo histórico, e que deve esperar, sem apelar para 0 acaso, mas aguardando das próprias forças da população brasileira, não o homem-herói, mas a Nação Heróica" (p.116). Essa contradição entre repúdio e aceitação do messianismo aparece em outros textos ligados à AIB.

${ }^{18}$ LEN H ARO, A. A sacralização da política. 2.ed. Campinas: Papirus, 1986, p.18.

${ }^{19} \mathrm{Em}$ muitas obras de autores integralistas a questão da religião é sempre discutida. Apesar de pregarem a liberdade de religião há uma clara identificação do futuro Estado Integral com o cristianismo: "O integral ismo quer inteira liberdade de confissão religiosa". Afirmando Deus e o Espírito, não pode o Estado Integral ser exclusivista em matéria de crença. Ele se põe de acordo com a luminosa encíclica Caritatis Cristi Compulsi de S. S. Pio $\mathrm{XI}$, a qual preconiza, para resistir ao materialismo dissolvente, a frente única, não só de todos "os que se orgulham do glorioso nome de cristão", como escreve textualmente o Sumo Pontífice, abraçando nessa designação larga e caridosa católicos, cismáticos e protestantes, como de "todos os que fazem de sua crença religiosa o fundamento da Ordem Social". BARROSO, G., op. cit., p.115. Num dos trechos de A quarta humanidade Plínio Sal gado observa as religiões existentes no Brasil e vê nas heranças indígenas e africanas um elemento fundamental para compreender vários aspectos históricos do país: "O estudo das manifestações religiosas das populações brasileiras, em que se mesclam a mitologia tupi e os ritos africanos, revela-nos o formidável potencial de energia mística expressivo notadamente nos grupos sociais do Nordeste. Há em nossa raça um notável poder religioso". SALGADO, P. O bras completas, cit., v.V, 1955, p.67-8.

${ }^{20}$ SEN N ETT, R. 0 declínio do homem público: as tiranias da intimidade. Trad. Lígia Araújo Watanabe. São Paulo: Companhia das Letras, 1993, p.190-242. 
${ }^{21}$ SALGAD O, P. O bras completas, cit., v.X, p.112.

${ }^{22} \mathrm{H}$ élgio Trindade lista alguns jornais integral istas de cidades do interior baiano, como: Alagoinhas, M aragogipe e Serrinha. TRIN DADE, H., op. cit., p.363.

${ }^{23} \mathrm{~A}$. Tenório $\mathrm{D}$ 'Albuquerque faz a seguinte afirmação sobre o regime liderado por Adolf Hitler e a impossibilidade de instalá-lo no Brasil: “O N azismo merecenos admiração, mas reconhecemos a inaplicabilidade do seu programa no Brasil. O seu rigorosismo contrasteia com o nosso espírito de rebeldia. Somos escandalosamente um povo de indisciplinados. Falta-nos espírito de ordem. No mais das vezes, recriminavelmente nos negamos a obedecer porque confundimos obediência com servilismo. Temos a preocupação dominadora de não ser escravos dos nossos superiores e tornamo-nos negligentes, não cooperamos para o progresso do Brasil e, por não nos queremos servilizar aos nossos chefes, escravizamoso Brasil ao banqueirismo internacional". D'ALBU QUERQUE, A.T. Integralismo, nazismo e fascismo: estudos comparativos. Rio de Janeiro: M inerva, 1937, p.80-1.

${ }^{24}$ Em CHASI N, J., op. cit., p.19.

${ }^{25}$ Em uma autocrítica escrita na década de 1950, Plínio Salgado analisa o papel dos aspectos exteriores do integralismo e como isso, em sua visão, atraiu elementos que confundiram-no com outros pensamentos políticos: “Essa doutrina política sofreu os prejuízos que Ihe advieram do seu próprio prestígio. As exterioridades de que se serviu para impressionar as massas levaram os espectadores superficiais a considerá-la segundo essas exterioridades. E até mesmo a maior parte dos que se enfileiraram no movimento integralista deixaram-se dominar por essas exterioridades, escapando à influência das idéias-fontes, portadoras das energias criadoras e independentes de representações adequadas a determinado momento histórico". SALGADO, P. Enciclopédia do Integralismo., cit., p.59. N otase em seu discurso um esforço de ressaltar a originalidade da doutrina do sigma, desvinculando-a de qualquer ligação com fascismo.

${ }^{26}$ DEBO RD, G. A sociedade do espetáculo. Trad. Estela dos Santos A breu. Rio de Janeiro: Contraponto, 1997, p.14. 